\title{
IMMUNOCYTOCHEMICAL LABELLING OF ISOLATED CATFISH PITUITARY GONADOTROPS WITH THE PROTEIN A-GOLD METHOD ON EPON SECTIONS
}

J. PEUTE, A.M.M. VAN PELT, J.L.M. LEUNISSEN \& R. DE LEEUW

Zoological Laboratory \& Institute of Molecular Biology, University of Utrecht, Padualaan 8 , Utrecht, The Netherlands

The adenohypophysis of catfish and other teleosts consists of morphologically and functionally different cell types. Hormone synthesis and release in some of these cell types are controlled by similar hypothalamic peptidergic and aminergic systems. In vivo also blood-born steroids may directly and/or indirectly influence the activity of for example corticotropic and gonadotropic pituitary cells. Moreover, different adenohypophyseal cell types tend to influence each other via their respective hormones, both under in vivo and in vitro conditions. Consequently, to study the effect of each single control mechanism on hormone synthesis and release by a single cell type, it is necessary to use isolated cells.

Confirmation of the identity of the isolated cell type is an important step in the procedure. The present study describes an ultrastructural method to confirm the isolation of gonadotropic cells from the pituitary of the African catfish, Clarias Zazera.

Dispersed pituitary gonadotropic cells were isolated on a discontinuous Percoll gradient. After separation, cell samples were fixed and epon-embedded according to standard procedures. Sections were collected on nickel grids, etched with $\mathrm{H}_{2} \mathrm{O}_{2} \quad 10 \%$ and treated with anti-Clarias gonadotropic hormone $(1: 5000)$ for $2 \mathrm{hr}$ at room temperature. Protein A-gold was used as the marker of the antibody. The pA-gold particles, with a diameter of $7 \mathrm{~nm}$, were prepared according to the method of van Bergen en Henegouwen and Leunissen (U1tramicroscopy, in press), with white phosphorus as the reducing agent (modified after Faulk and Taylor, Imnunochemistry 8, 1081, 1971). In the gonadotrops secretory granules, globules and large secretory masses were strongly inmunolabelled, whereas the cytoplasm was completely devoid of gold particles. Immunolabelling was absent in the other pituitary cell types. It appears that imtunolabelling with the homologous antibody and pArgold particles on fixed and epon-embedded cells, gives a specific localization of the hormone, combined with a good structural preservation.

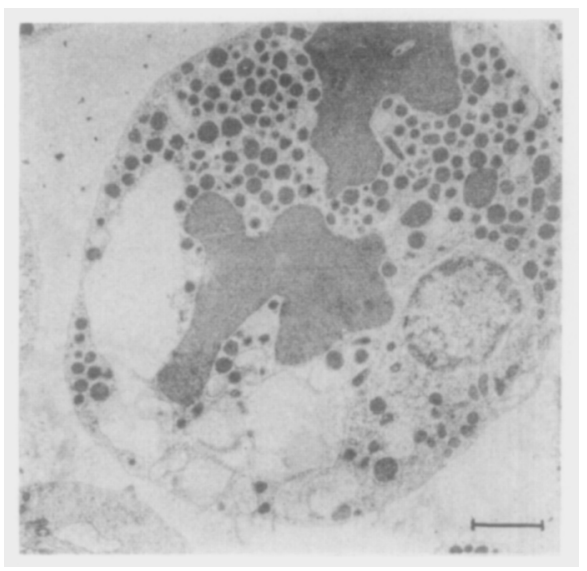

Fig. 1. Gonadotropic cell of one of the fractions. I'he bar represents $2100 \mathrm{~nm}$.

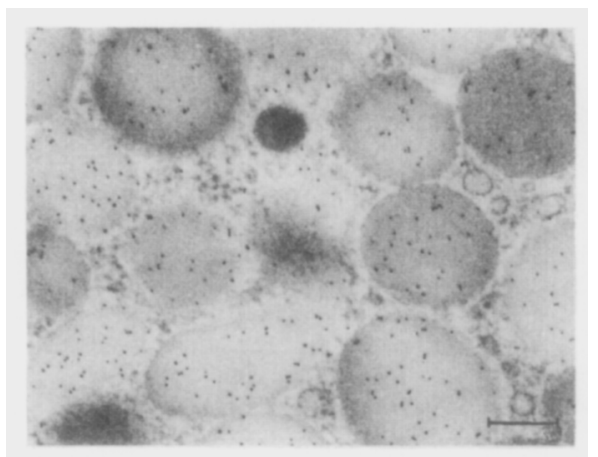

Fig. 2. Part of an isolated gonadotropic cell; epon section treated with antibody and pA-gold. The bar represents $226 \mathrm{rm}$.

Received: 13th February 1984 Accepted: 21st February 1984 